Article

\title{
Climate Predictions Accelerate Decline for Threatened Macrozamia Cycads from Queensland, Australia
}

\section{Melinda J. Laidlaw * and Paul I. Forster}

Queensland Herbarium, Department of Science, Information Technology, Innovation and the Arts, Brisbane Botanic Gardens, Mt Coot-tha Rd, Toowong 4066, Australia;

E-Mail: Paul.Forster@science.dsitia.qld.gov.au

* Author to whom correspondence should be addressed;

E-Mail: melinda.laidlaw@science.dsitia.qld.gov.au; Tel.: +61-7-3896-9323 Fax: +61-7-3896-3254.

Received: 3 October 2012; in revised form: 26 November 2012 / Accepted: 7 December 2012 / Published: 14 December 2012

\begin{abstract}
Changes in the potential habitat of five allopatric species of threatened Macrozamia cycads under scenarios of increased ambient temperature were examined. A lack of seed dispersal, poor recruitment, low seedling survival, obligate pollinator mutualisms and continued habitat loss have led to extant populations being largely restricted to refugia. Models predict that the area of suitable habitat will further contract and move upslope, resulting in a reduced incidence within protected areas with increasing annual mean temperature. Areas of potential habitat for all five species are also predicted to become increasingly isolated from one another, further reducing the exchange between metapopulations and subpopulations, exacerbating existing threatening processes.
\end{abstract}

Keywords: climate change; conservation planning; cycads; distribution; Macrozamia; Maxent; Queensland, Australia; threatened species

\section{Introduction}

The cycads (Cycadophyta: families Cycadaceae, Zamiaceae [1]) comprise dioecious, long-lived woody gymnosperms that have a perennial caudex or trunk and leaves that are shed and renewed over a period of several years. Cycads can be considered as 'flagship species' for conservation biology [2,3], as they have unusual life histories, are generally restricted in distribution, with over 50\% of species threatened globally [4,5], and are of commercial interest to horticulture. Cycads as a group 
are considered to be in global decline due to climate change over time and their inability to outcompete most angiosperms [6].

Cycads are often referred to as the 'dinosaurs of the plant world' and certainly, the ancestral lineages of the current-day species were contemporaneous with dinosaurs, although it is likely that the extant genera (and component species) are relatively recently evolved [7,8]. Some authors consider that the surviving species of cycads are in an evolutionary dead-end and awaiting final extinction [6,9]; however, all species (and individual populations) have an origin, expansions and contractions of range, decline and an eventual extinction [10]. Many cycad species may be of recent origin, with species radiations since the Pleistocene (1.75 million-10,000 years ago) [11], although it has been postulated that the average length of time that a cycad species has existed for is about 54 million years [10].

Most species of cycads occur in populations that are often disjunct and with little evidence of genetic flow between them. Incipient inbreeding occurs within many populations [12-16]. It is perhaps unlikely that disjunct populations (even those that are geographically adjacent) of most cycad species behave as part of a dynamic 'metapopulation', where the local populations are regularly connected by dispersing individuals or have a flow of genetic material with the potential to recolonise or augment adjacent populations [17-19]. Rather, cycads fit a 'regional ensemble' model [20], with systems of essentially unconnected local populations persisting in an ill-defined mosaic of suitable and unsuitable habitat.

Most cycads appear to be characterised by dispersal-limited distributions [21], with sharp population boundaries, despite adjacent similar habitat [22,23]. Dispersal of seeds is local (less than $100 \mathrm{~m}$ from the parent), rather than long-distance (more than $100 \mathrm{~m}$ sensu [24]). Many of any resultant cycad seedlings are destroyed by events such as fire, competition or predation. Cycads are also generally absent from areas of disturbance or succession, where rapid establishment of individuals is an advantage [25]. This characteristic of reproductive failure drives a lack of contact between populations and probably has resulted in apparent speciation (reflected in morphological differences) via genetic drift rather than selection [26,27].

Macrozamia cycads are endemic to Australia, with forty-one species currently recognised and classified into two taxonomic sections [28-30]. Species of Macrozamia classified in M. section Parazamia are characterised by a subterranean caudex, leaves that are easily twisted off the stem and that have soft wool at the expanded base and leaflets that lack mucilage canals. Nearly all Macrozamia species from this section occur in few to numerous populations that vary in size from a handful of individuals to many thousands, and the majority of listed threatened (Endangered or Vulnerable) Macrozamias are from this group.

In the Darling Downs district of south-east Queensland in eastern Australia (Figure 1), there are currently recognised five, morphologically similar species from $M$. section Parazamia (M. cranei D.L.Jones \& P.I.Forst., M. conferta D.L.Jones \& P.I.Forst., M. machinii P.I.Forst. \& D.L.Jones, $M$. occidua D.L.Jones \& P.I.Forst. and M. viridis P.I.Forst. \& D.L.Jones). These five species occur allopatrically in generally consistent habitat types, but appear to share common reproductive traits of thermogenic male and female cones and a common pollinating beetle (the weevil Tranes) [31-33] and are probably biologically compatible if individuals from populations could interact genetically. They may be the result of a relatively recent speciation event [29], probably post-Pleistocene, as has been proposed for other cycads [11,27,34]. An alternative hypothesis is that they comprise five 
metapopulations of a single, highly variable 'superspecies' (referred to here as Macrozamia super spp.); either way, it is likely that they share a complex history of lineage interactions involving intermittent contact between populations, both within and between the currently recognised species.

Figure 1. Current modelled range and species records of five Macrozamia species in the Darling Downs region of Queensland, Australia. Hatching indicates the extent of the current range covered by remnant vegetation.

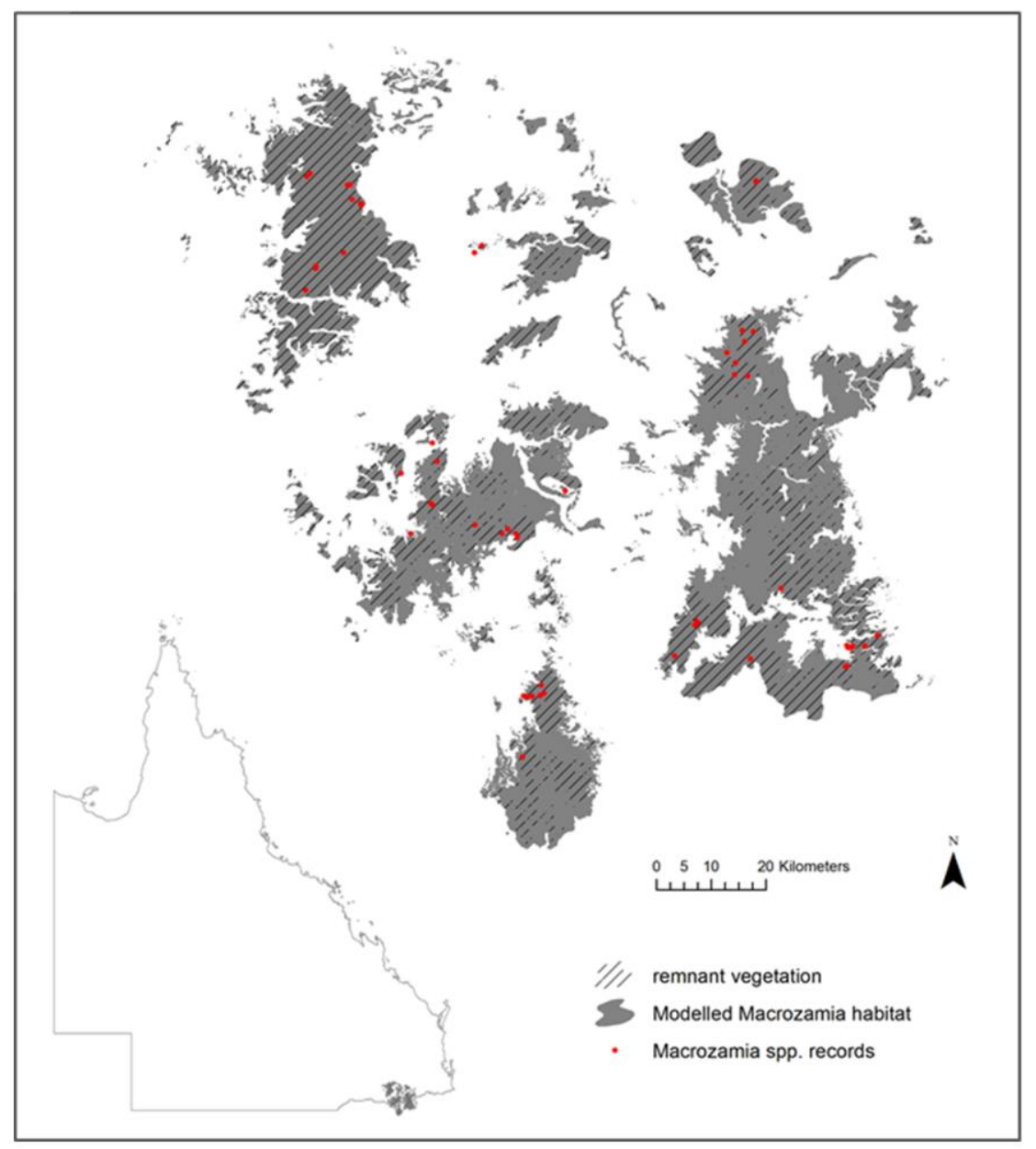

All five species are listed as threatened under Queensland's Nature Conservation Act 1992 as either 'Endangered' (M. cranei and M. viridis) or 'Vulnerable' (M. conferta, M. machinii and M. occidua). Four are also listed federally under the Environment Protection and Biodiversity Conservation (EPBC) Act 1999 as 'Endangered' (M. cranei) or 'Vulnerable' (M. conferta, M. machinii and M. occidua). Two (M. cranei and M. viridis) are listed as 'Endangered', and the remaining three are listed as 'Vulnerable' on the IUCN red list. The current, fragmented distribution of the populations for these five species is an indication that they are largely in the 'decline' phase of species duration [10]. Many of the populations are very small (fewer than 100 adults) with little evidence of recruitment and may already be unviable in the long term. Individuals of these or similar cycads are long-lived (life span ranges of 60 to 1,500 years have been given for Macrozamia species [35,36]), resilient to fire and some forms of mechanical disturbance. In predicting future movements of species along with climate, species distribution models assume that species are in equilibrium with their environment [37,38]. This 
is difficult to assess if it is not known if a species is currently at its biophysical limits or if other factors are restricting its range [38]. In the case of the study species, which are long lived, exhibit low dispersal ability, but which are still reproducing in situ, we acknowledge that some extant adult individuals may have germinated under a different climate regime. These persistent 'survivors' seem capable of existing in small numbers; however, they are thought to be the last remnants of once healthy populations and may in reality be the 'living dead' in a biological sense, particularly if the obligate pollinators have been lost from individual populations.

\section{Experimental Section}

The species studied occur in the Darling Downs region of South-east Queensland (Figure 1), which experiences an annual average temperature of $11.9{ }^{\circ} \mathrm{C}-18.4{ }^{\circ} \mathrm{C}$ and an annual mean precipitation of 602-1,061 mm. Within a spatial context, these Macrozamia cycads exist on heavily weathered, nutrient poor soils derived from the remnants of a highly subdued landscape relief. The landscape is fragmented both from natural discontinuities in geology and associated ecosystems, compounded by land clearing for agriculture. Although much of the study region is covered by remnant vegetation (Figure 1), it is acknowledged that not all current or future land uses are compatible with the survival of Macrozamia cycads. Despite this, potential habitat has been modelled irrespective of land use with a view to its suitability for the restoration of Macrozamia habitat.

The populations of all five species have been extensively surveyed and the full extent of the species is believed to be known. Data used for potential habitat modelling represent specimen-backed records sampled from these populations and lodged with the Queensland Herbarium, vetted for taxonomic and spatial accuracy. Duplicate species presence records within an $83 \mathrm{~m}$ cell were excluded to reduce collection bias. The records for all five species were also pooled and modelled as a 'superspecies' (Macrozamia super spp.) comprising five metapopulations in acknowledgement of their putative close relationship [14,29,39].

The Maxent (3.3.3k) maximum entropy algorithm was used to model the potential habitat for all five Macrozamia species, as well as their 'superspecies'. Records collected along roads were down-weighed to half the value of those collected away from roads to ensure the potential habitat models reflect each species' known distribution, rather than the degree of sampling effort employed [40]. Seven uncorrelated predictor variables (pairwise Pearson correlations $<0.83$ ) considered to be functionally relevant to Macrozamia cycads were used to model all species. Four historic climatic variables, annual mean temperature, temperature seasonality (coefficient of variation), annual precipitation and mean moisture index of the lowest quarter moisture index, were derived using Anuclim 5.1 software [41] and an 83m digital elevation model (DEM). Topographic ruggedness was calculated from the DEM as the range in elevation covered by the eight cells surrounding each focal cell. Pre-clearing broad vegetation group (1:1M scale) and land zone, a classification of substrate and geomorphology, were also used as categorical predictor variables.

Maxent models were trained on the predictor variables describing the observed historical base climate, then projected to predictor variables, where annual mean temperature was replaced with modelled future annual mean temperature values for the years 2030, 2050, 2070 and 2100 under two different emission scenarios. The A1B emission storyline describes a mid-line, 'business as usual' 
scenario of global economic growth, low population growth and a move towards a balancing of fossil fuel use with other sources of energy [42]. It assumes a moderate rate of global warming of approximately $2.6{ }^{\circ} \mathrm{C}$ with a doubling of atmospheric carbon from 280-560 ppm [42]. The second emission scenario used, A1FI, assumes a higher rate of global warming of $4.2{ }^{\circ} \mathrm{C}$ for a doubling of CO2 from 280-560 ppm and describes a world of increasing globalisation, economic growth and fossil fuel use [42]. For both scenarios, the Max Planck: ECHAM5/MPI-OM global climate model was selected for the prediction of future temperature conditions, as it produces a moderate annual warming response in comparison to other climate models [42]. In general, this model describes an increase in annual mean temperature across all of Australia, but with smaller increases along the southern coast [42].

A mask was created for each species by buffering a minimum convex hull incorporating all records by $200 \mathrm{~km}$. A $200 \mathrm{~km}$ buffer has been shown by VanDerWal et al. [43] to produce a model that both generalises well across a range of environmental conditions and does not over-inflate predicted distributions at the expense of finer environmental gradients. Maxent uses the masks to restrict the selection of background points (or pseudoabsences) to the region of species [43], ensuring that the model reflects the distribution of a species rather than the distribution of an environmental predictor [40]. Ten thousand random background samples were selected within the mask. Clamping was applied to restrict predictor values outside of the masked area to the range of values within the masked area [44]. Models were fitted using linear, quadratic and hinge features. A 'tenth percentile training presence' threshold was applied to all species to modify continuous logistic (0-1) Maxent outputs to a binary map of potential species distribution. This is a conservative threshold, which may lead to the occasional omission of presence records (e.g., Figure 2e). A majority filter algorithm was applied to both remove 'orphan' cells and smooth the margins of the distribution.

Due to their restricted geographical range, only small numbers of presence records were available (Table 1), and as such, no data were quarantined for model testing. Instead, the accuracy of the distribution models was assessed via the area under the receiver operator curve (AUC). AUC indicates the ability of a model to distinguish between presence and absence [37]. The modelled AUC was compared to the $95 \%$ confidence interval upper limit AUC produced from 1000 null models of randomly selected sites chosen without replacement from within the bounds of a $200 \mathrm{~km}$ mask for each species [45].

Table 1. Contribution of annual mean temperature and temperature seasonality to each Macrozamia model, model AUC value and 95\% confidence interval (CI) AUC values of the randomly drawn null-models $(\mathrm{n}=1,000)$.

\begin{tabular}{cccccc}
\hline Species & n & $\begin{array}{c}\text { Mean annual } \\
\text { temperature } \\
\text { permutation } \\
\text { importance (\%) }\end{array}$ & $\begin{array}{c}\text { Temperature } \\
\text { seasonality } \\
\text { permutation } \\
\text { importance (\%) }\end{array}$ & $\begin{array}{c}\text { Modelled } \\
\text { AUC }\end{array}$ & $\begin{array}{c}\mathbf{9 5 \%} \\
\text { CI } \\
\text { AUC }\end{array}$ \\
\hline Macrozamia conferta & 12 & 0 & 0.9 & 0.992 & 0.935 \\
Macrozamia cranei & 13 & 54.6 & 43.2 & 0.993 & 0.938 \\
Macrozamia machinii & 18 & 58.4 & 10.6 & 0.993 & 0.899 \\
Macrozamia occidua & 5 & 88 & 8.2 & 0.998 & 0.995 \\
Macrozamia viridis & 11 & 89.3 & 3.7 & 0.994 & 0.983 \\
Macrozamia super spp. & 59 & 60.5 & 31.6 & 0.982 & 0.829 \\
\hline
\end{tabular}




\section{Results and Discussion}

All species models performed significantly better (95\% CI) than random when compared to 1000 null models of randomly selected locations from masks used for background point selection (Table 1). For four of the five species examined, and at the 'superspecies' level (Macrozamia super spp.), annual mean temperature (54.6-89.3\% permutation importance) and temperature seasonality (3.7-43.2\% permutation importance) were found to be limiting factors. Together, these two variables contributed $69-97.8 \%$ (mean $89.6 \% \pm$ SE $5.26 \%$ ) of the permutation importance, demonstrating the sensitivity of a majority of this group to temperature perturbation. The exception, M. conferta, is not driven by temperature (Table 1). Instead, it is limited by land zone (65.8\%) and broad vegetation group (24.6\%). Its current distribution is restricted to eucalyptus forest/woodland on poor soils of either silty loam or shallow rocky skeletal soils [14,39].

The ranges of all species, as well as the 'superspecies', are predicted to become increasingly restricted within Queensland with increasing annual mean temperature (Figure 2). Range reduction is more pronounced under the A1FI emissions scenario in all cases. The area of potential habitat continually reduces with increasing annual mean temperature with two species, M. machinii and $M$. viridis having no potential habitat modelled at 2100 under the A1FI emissions scenario (Figure 3). Under both the A1B and A1FI emission scenarios, the range of M. conferta is predicted to become increasingly restricted around current presence records (Figure 2a) and for this area to remain as potential habitat up until at least the end of the century. The current distribution of this species may represent refugial populations restricted to this area under past climatic perturbations. The apparent dispersal limited distribution and the biological features that result in these traits appear to have historically 'imprisoned' each population within their refugial area. This is further compounded by the lack of suitable habitat in adjacent areas. Hence, the projected reduction in suitable habitat area paints a dire future scenario for this particular species.

The area of potential habitat found within the current protected area estate is predicted to decline over time for most species (Figure 3). This situation is particularly serious for $M$. cranei, as none of its known populations are currently protected within reserves. Approximately $8 \%$ of this species' modelled potential habitat is currently afforded some protection in National Park and various State Forests; however, this is predicted to decline to less than $5 \%$ of its potential distribution by midcentury (Figure 3b). Remnant vegetation on private lands where the species is currently found could be considered for greater protection. Uniquely, the modelled range of $M$. conferta within protected areas remains largely consistent, despite the reduction in overall area with increasing annual mean temperature (Figure 3a). This indicates that the current location of protected areas will remain important for this species into the future.

The elevation range of suitable potential habitat restricts with increasing annual mean temperature for all species (Figure 4). The upper elevational range limits for M. conferta, M. occidua and the 'superspecies' (Macrozamia super spp.) remain constant over time, while the lower limit of their distribution is predicted to rise under both the A1B and A1FI emission scenarios. Macrozamia cranei, M. machinii and $M$. viridis are predicted to experience a restriction towards the middle of their current elevation range that is more pronounced under the A1FI emissions scenario. This may be extremely pronounced in the case of $M$. cranei (Figure 4b). 
Figure 2. Predicted changes in the range of Darling Downs Macrozamia cycads with increasing annual mean temperature under A1B and A1FI emission scenarios (a) M. conferta. (b) M. cranei. (c) M. machinii. (d) M. occidua. (e) M. viridis and (f) Macrozamia super spp.

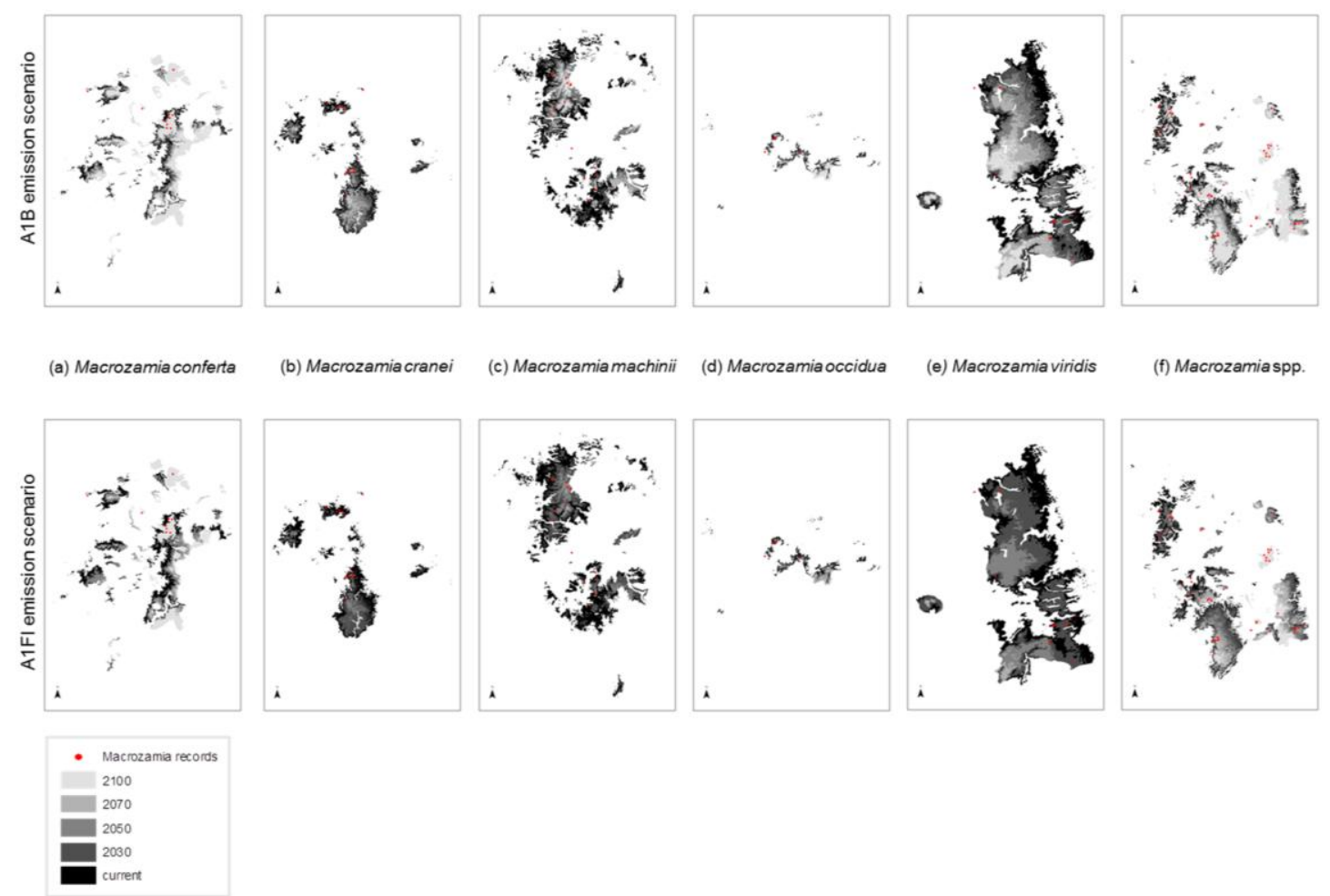

Although we have only examined possible in situ upslope movement for these species, possible range movement south across the state border into New South Wales should be considered, where the related M. plurinervia occurs [14]. The lack of dispersal ability, coupled with extremely slow generational turnover, are likely biological traits preventing these species from shifting or expanding spatially at any substantial rate.

The degree to which the areas of predicted future habitat for each species coincide was examined by stacking individual species models on top of each other (Figure 5). Some areas are highlighted as potential habitat suitable for two or three Macrozamia species, perhaps suggesting that greater exchange has occurred between these species in the past. The inferred phylogenetic hypothesis for this group of species is that they share a common ancestral lineage, and this is reflected in genetic similarities, though not uniformity ([14]; Ingham, unpublished data). This hypothesis encompasses the concept that the ancestral lineage (viz. a 'superspecies') fragmented into populations that became further separated into metapopulations with restriction to refugial areas or with some local migration. Past climate changes are likely to have been the primary drivers of fragmentation of the 'superspecies' yielding the present isolated distributions, although it is unlikely to have been a single event, rather a recurring pattern of expansion and contraction for this group. Figure 5 also suggests decreasing overlap in predicted ranges through time. This increasing isolation coupled with inbreeding and increasing genetic drift between members of the 'superspecies' has resulted in a group of similar species with relatively minor morphological and genetic differences. As such, they can be interpreted as an example of 'non-radiation', where there is a low lineage, diversification rate (i.e., unsuccessful in terms of species production and ecological/morphological diversification) [46]. 
Figure 3. Predicted changes in the total area of potential habitat and area within protected areas of Darling Downs Macrozamia cycads and with increasing annual mean temperature under A1B and A1FI emission scenarios (a) M. conferta, (b) M. cranei, (c) M. machinii, (d) M. occidua, (e) M. viridis and (f) the 'superspecies' Macrozamia super spp.

(a) M. conferta

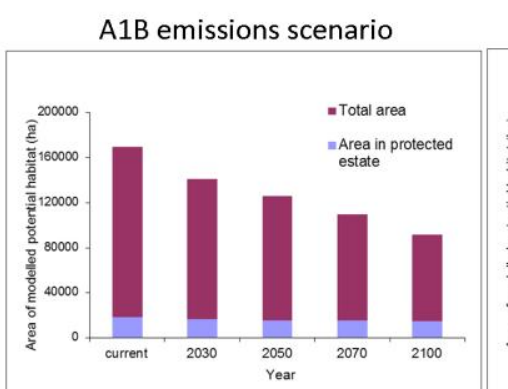

A1FI emissions scenario

(b) M. cranei

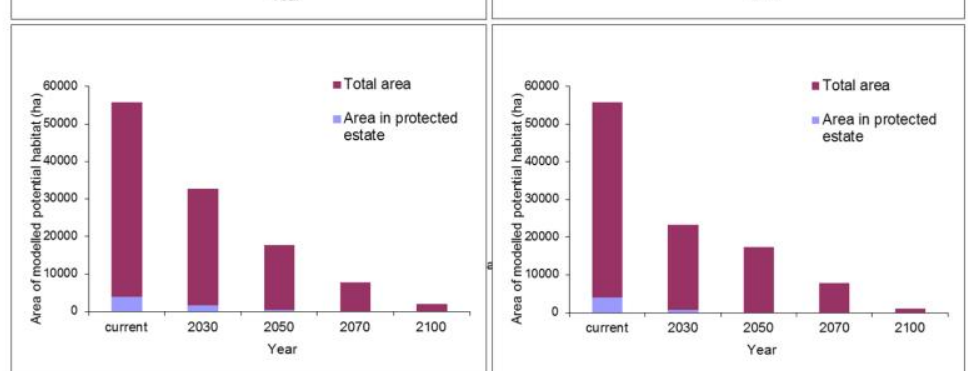

(c) M. machinii
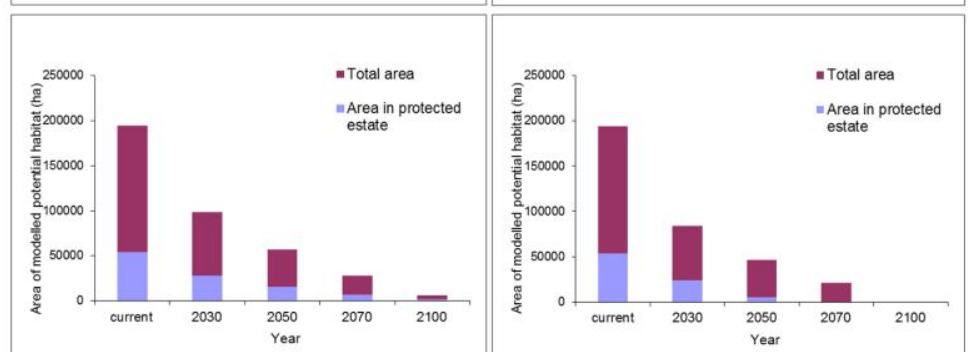

(d) M. occidua

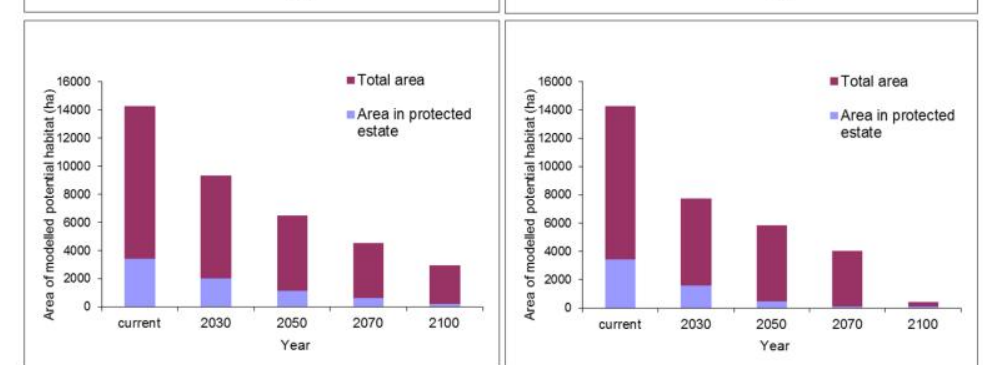

(e) $M$. viridis

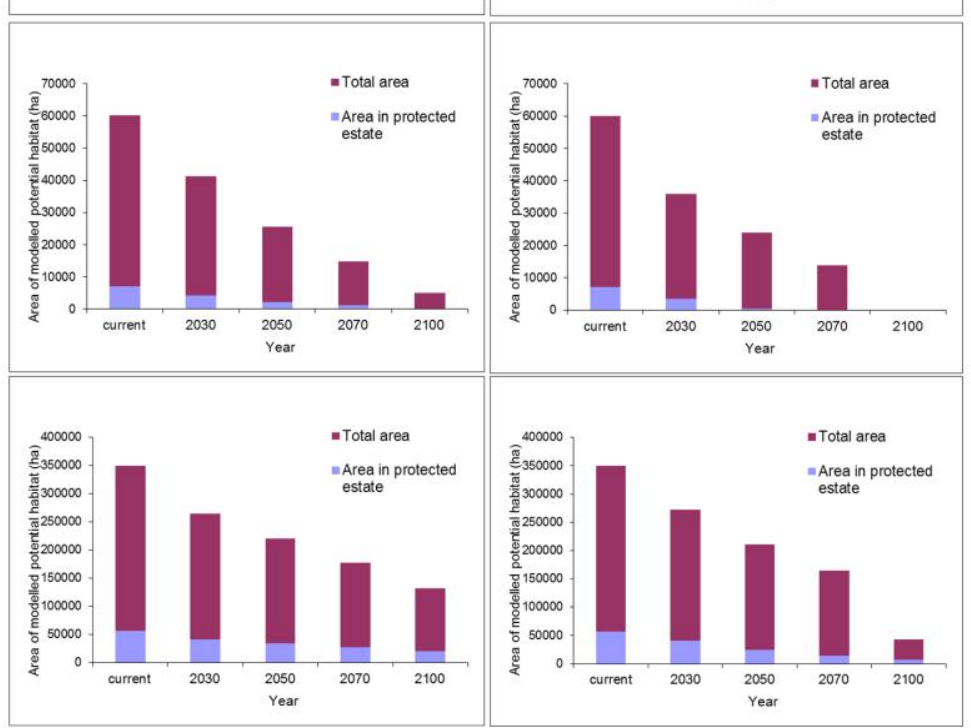


Figure 4. Maximum $(\max )$ and minimum $(\min )$ elevations of potential habitat ranges modelled for Darling Downs Macrozamia cycads with increasing annual mean temperature under A1B and A1FI emission scenarios (a) M. conferta, (b) M. cranei, (c) M. machinii, (d) M. occidua, (e) M. viridis and (f) Macrozamia super spp.
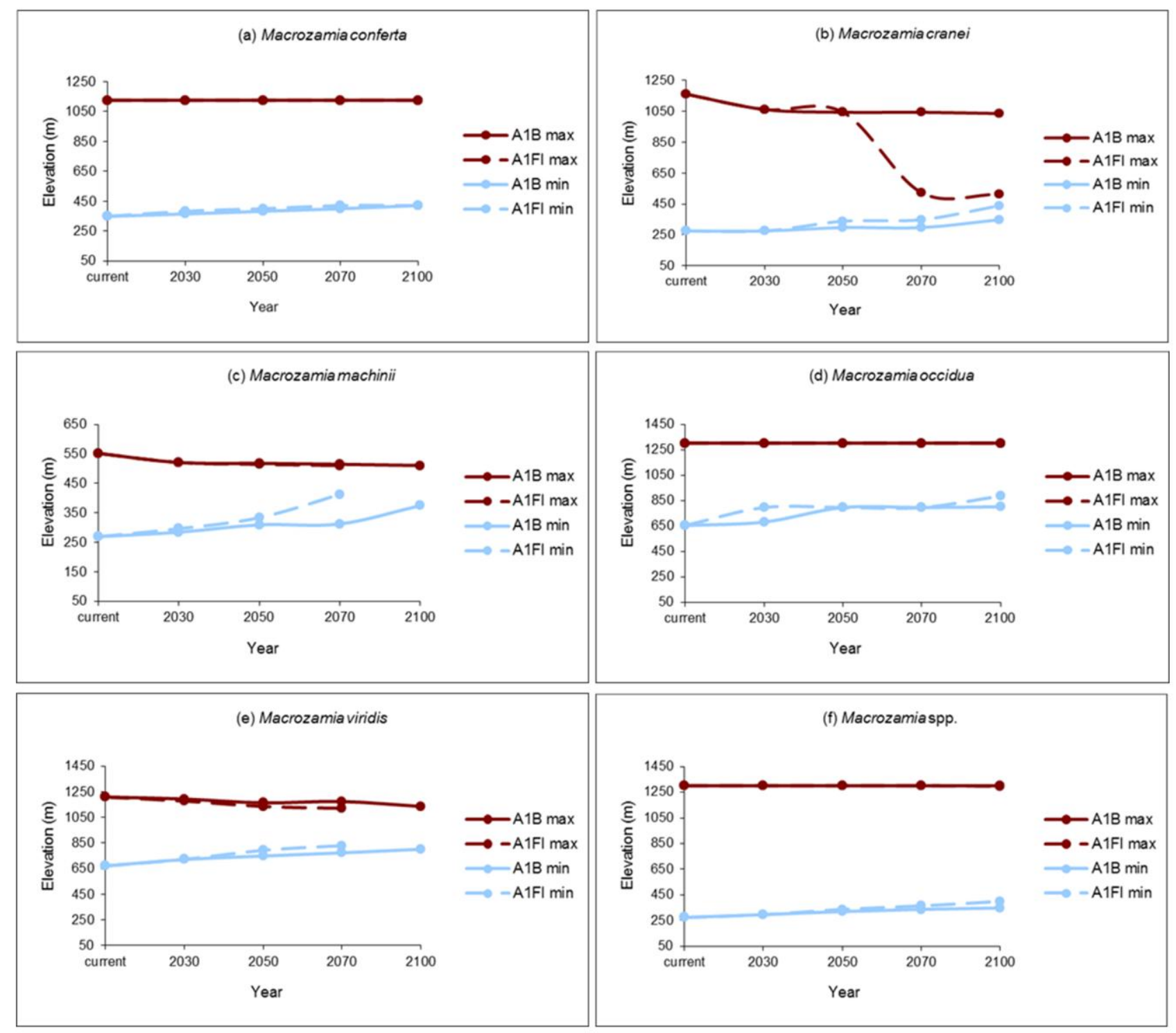

The future survival and role of specialized mutualist pollinators (Tranes beetles) [31-33,47-49] is a further compounding biological feature. The impacts of increasing annual mean temperature on these Tranes spp. beetles is largely unknown. Energetic rewards via thermogenic cycad cones may be reduced as ambient temperatures increase, particularly in the evenings, when pollination occurs. Temperature plays a primary role in controlling all stages of plant reproduction [50]; however, its role in controlling thermogenesis and its cues in cycad cones remains unclear. Roemer et al. [48,49] found that ambient temperatures are important in the initiation, magnitude and timing of cone temperature oscillations for several Macrozamia cycads (M. macleayi, M. lucida). Increasing ambient temperatures trigger thermogenic events in these species, so an increase in these temperatures may result in earlier coning cycles for these Macrozamias; whether the beetles can adapt to these changes remains to be seen. 
Figure 5. Modelled potential habitat for five threatened Macrozamia species in the Darling Downs region of Queensland, Australia under (a) current (historic) climate or with increasing annual mean temperatures under A1B and A1FI emission scenarios predicted in (b) 2030, (c) 2050, (d) 2070 and (e) 2100. Colours refer to the number of overlapping species models at a location.
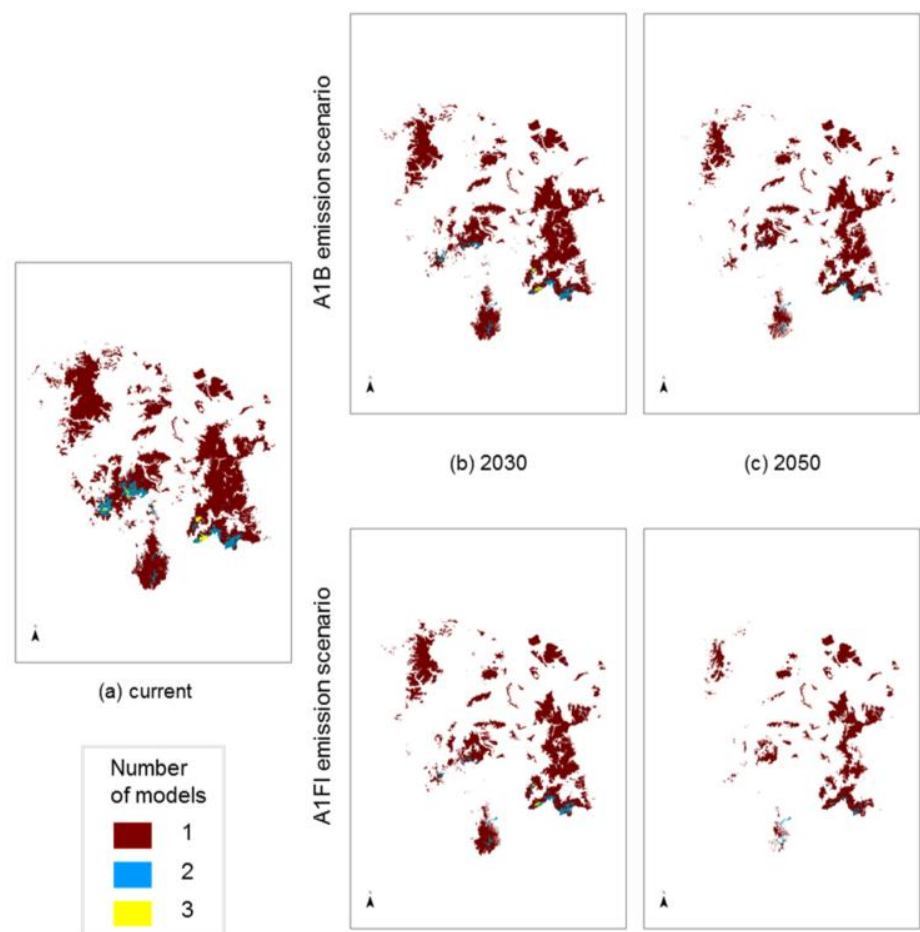

(c) 2050

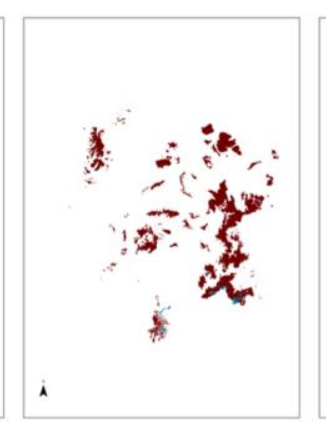

(d) 2070

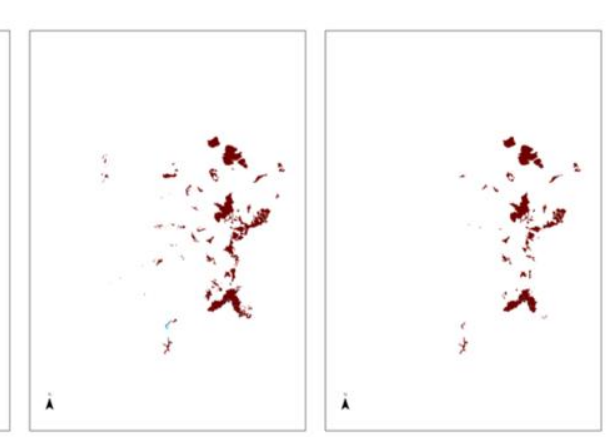

If the four critical questions by Schemske et al. [51] about species viability are addressed for these species, in conjunction with the conclusions reached for the biologically similar cycad M. platyrhachis [23], then the projected scenarios of temperature increases can be responded to thus:

\section{Question 1 - Biological status of the species}

Are individuals and populations of the species increasing, decreasing or stable?

\section{Likely to decrease.}

\section{Question 2 - Life history}

What stages are limiting population growth and species persistence? (a) Lack of seed dispersal, (b) poor recruitment as exhibited by extremely low current seedling survival and (c) adult plant dependence on a specific insect pollination mutualism for reproduction make these species highly sensitive to disturbances.

\section{All three features are likely to be impacted negatively.}

\section{Question 3 - Biological causes of variation in life history}

What causes have the most demographic impact? (a) Lack of dispersal agents result in short $(<100 \mathrm{~m})$ or no seed dispersal. This limits range expansion and also results in inbreeding depression due to recruitment of siblings. (b) The long generation time (probably 20-25 years, 60-80 years for 
three generations) and the highly unpredictable nature of coning events likely contributes to variability in pollinator populations, fertilization and population recruitment.

\section{Negative impact predicted.}

\section{Question 4 - Geographical and physical constraints}

Is there room to move? The species are restricted to areas of unique geology and topology in Queensland and are not likely to colonize outside of these areas. There are large areas that appear to be suitable habitat within the known area of occurrence, but lack of seed dispersal appears to limit expansion outside the population boundaries.

Unlikely to be able to move and in most instances, nowhere to move to; particularly in areas where clearing of vegetation for agriculture has occurred or is ongoing.

\section{Conclusions}

An increase in ambient temperatures as predicted under certain climate models is likely to have an adverse effect on the five species of threatened Macrozamia cycads discussed. The models indicate that the area of suitable habitat will decrease and move upslope, thus further restricting species and populations into smaller and smaller refugial areas. The models also indicate that most of the species are already in refugial areas. Biological attributes of the cycads, such as limited dispersal that is controlling distribution, slow generational turnover and obligate pollination mutualisms (beetle pollination and thermogenic cones) are already 'imprisoning' the populations in refugia. In most instances, it is unlikely that the fragmented populations of either the individual species or the overall 'superspecies' will merge together under these climate prediction scenarios, nor will they be able to move at the rate necessary to keep up with change.

Long term conservation of these 'flagship' species and the unique pollination mutualisms associated with them will involve careful monitoring of the health of individual populations, together with specialized management of the 'core' populations in refugial areas. Maintaining the overall assemblage of populations is likely to prove difficult, and comprehensive knowledge of individual population genetics is essential if informed decisions about species, population or individual rescue with subsequent 'assistance', such as augmentation, are to be successful. As individual adult plants are long-lived and resilient to the extremes of environmental variables, it is likely that they may persist in these areas for a long time, albeit as the 'living dead'.

\section{Acknowledgments}

The authors thank Gordon Guymer, Michael Mathieson, Don Butler, Rosemary Niehus, Jiaorong Li, Jim Ricketts and John Carter for their valuable advice and technical assistance.

\section{References}

1. Hill, K.D.; Chase, M.W.; Stevenson, D.W.; Hills, H.G.; Schutzman, B. The families and genera of cycads: A molecular phylogenetic analysis of Cycadophyta based on nuclear and plastid DNA sequences. Int. J. Plant Sci. 2003, 164, 933-948. 
2. Given, D.R. Principles and Practice of Plant Conservation; Timber Press: Portland, OR, USA, 1994.

3. Meffe, G.K.; Carroll, C.R. Principles of Conservation Biology, 2nd ed.; Sinauer Associates Inc. Publishers: Sunderland, MA, USA, 1997.

4. Donaldson, J.S. Cycads, A Status Survey and Action Plan; IUCN-The World Conservation Union: Gland, Switzerland, 2003.

5. Donaldson, J.S. Saving Ghosts? The implications of taxonomic uncertainty and shifting infrageneric concepts in the Cycadales for Red Listing and conservation planning. In Cycad Classification: Concepts and Recommendations; Walters, T., Osborne, R., Eds.; CAB International Publishing: Wallingford, UK, 2004; pp. 13-22.

6. Norstog, K.J.; Nicholls, T.J. The Biology of the Cycads; Cornell University Press: London, UK, 1997.

7. Crisp, M.D.; Cook, L.G. Cenozoic extinctions account for the low diversity of extant gymnosperms compared with angiosperms. New Phytol. 2011, 1992, 997-1009.

8. Nagalingum, N.S.; Marshall, C.R.; Quental, T.B.; Rai, H.S.; Little, D.P.; Mathews, S. Recent synchronous radiation of a living fossil. Science 2011, 334, 796-799.

9. González-Astorga, J.; Vovides, A.P.; Iglesias, C. Morphological and geographic variation of the cycad Dioon edule Lindl. (Zamiaceae): Ecological and evolutionary implications. Biol. J. Linn. Soc. 2003, 141, 465-470.

10. Levin, D.A. The Origin, Expansion, and Demise of Plant Species; Oxford University Press: Oxford, UK, 2000.

11. van der Bank, F.H.; Wink, M.; Vorster, P.; Treutlein, J.; Brand, L.; van der Bank, M.; Hurter, J. Allozyme and DNA sequence comparisons of nine species of Encephalartos (Zamiaceae). Biochem. Syst. Ecol. 2001, 29, 241-266.

12. Sharma, I.K.; Jones, D.L.; Forster, P.I.; Young, A.G. The extent and structure of genetic variation in the Macrozamia pauli-guilielmi complex (Zamiaceae). Biochem. Syst. Ecol. 1998, 26, 45-54.

13. Sharma, I.K.; Jones, D.L.; Forster, P.I.; Young, A.G. Low isozymic differentiation among five species of the Macrozamia heteromera group (Zamiaceae). Biochem. Syst. Ecol. 1999, 27, 67-77.

14. Sharma, I.K.; Jones, D.L.; Forster, P.I. Genetic differentiation and phenetic relatedness among seven species of the Macrozamia plurinervia complex (Zamiaceae). Biochem. Syst. Ecol. 2004, $32,313-327$.

15. Keppel, G. Low genetic variation in a Pacific cycad: conservation concerns for Cycas seemannii (Cycadaceae). Oryx 2002, 36, 41-49.

16. Keppel, G.; Lee, S.-W.; Hodgskiss, P.D. Evidence for long isolation among populations of a Pacific Cycad: genetic diversity and differentiation in Cycas seemannii A.Br. (Cycadaceae). J. Heredity 2002, 93, 133-139.

17. Hanski, I.; Gilpin, M. Metapopulation dynamics: brief history and conceptual domain. Biol. J. Linn. Soc. 1991, 42, 3-16.

18. Eriksson, O. Regional dynamics of plants: a review of evidence for remnant, source-sink and metapopulations. Oikos 1996, 77, 248-258.

19. Wakeley, J. Metapopulation models for historical inference. Mol. Ecol. 2004, 13, 865-875. 
20. Freckleton, R.P.; Watkinson, A.R. Large-scale spatial dynamics of plants: metapopulations, regional ensembles and patchy populations. J. Ecol.2002, 90, 419-434.

21. Primack, R.B.; Miao, S.L. Dispersal can limit local plant distribution. Conserv. Biol. 1992, 6, 513-519.

22. Snow, E.L.; Walter, G.H. Large seeds, extinct vectors and contemporary ecology: testing dispersal in a locally distributed cycad, Macrozamia lucida (Cycadales). Aust. J. Bot. 2007, 55, 592-600.

23. Terry, I.; Forster, P.I.; Moore, C.J.; Roemer, R.B.; Machin, P.J. Demographics, pollination syndrome and conservation status of Macrozamia platyrhachis (Zamiaceae), a geographically restricted Queensland cycad. Aust. J. Bot. 2008, 56, 321-332.

24. Cain, M.L.; Milligan, B.G.; Strand, A.E. Long-distance seed dispersal in plant populations. Am. J. Bot. 2000, 87, 1217-1227.

25. Bond, W.J. The tortoise and the hare: Ecology of angiosperm dominance and gymnosperm persistence. Biol. J. Linn. Soc. 1989, 36, 227-249.

26. Gorelick, R. Evolution of cacti is largely driven by genetic drift, not selection. Bradleya 2009, 27, $37-48$.

27. Forster, P.I. Cycas terryana P.I.Forst. (Cycadaceae), a new species from central Queensland. Austrobaileya 2011, 8, 356-363.

28. Jones, D.L. Cycads of the World, 2nd ed,; Reed New Holland: Sydney, Australia, 2002.

29. Forster, P.I. Classification concepts in Macrozamia (Zamiaceae) from Eastern Australia. In Cycad Classification: Concepts and Recommendations; Walters, T., Osborne, R., Eds.; CAB International Publishing: Wallingford, UK, 2004; pp. 85-94.

30. Ingham, J.A.; Forster, P.I.; Crisp, M.; Cook, L.G. Ancient relicts or recent dispersal: how long have cycads been in central Australia? Divers. Distributions 2012, doi: 10.1111/j.1472-4642.2012.00936.x.

31. Forster, P.I.; Machin, P.J.; Mound, L.; Wilson, G.W. Insects associated with reproductive structures of cycads in Queensland and northeast New South Wales, Australia. Biotropica 1994, 26, 217-222.

32. Terry, I.; Moore, C.J.; Walter, G.H.; Forster, P.I.; Roemer, R.B.; Donaldson, J.D.; Machin, P.J. Association of cone thermogenesis and volatiles with pollinator specificity in Macrozamia cycads. Plant Syst. Evol. 2004, 243, 233-247.

33. Terry, I.; Walter, G.H.; Donaldson, J.D.; Snow, E.L.; Forster, P.I.; Machin, P.J. Pollination of Australian Macrozamia cycads: Effectiveness and behavior of specialist vectors in a dependent mutualism. Am. J. Bot. 2005, 92, 931-940.

34. Vovides, A.P.; Pérez-Farrera, M.A.; Gonzáles-Astorga, J.; Gonzáles, D.; Gregory, T.; Chemnick, J.; Iglesias, C.; Octavio-Aguilar, P.; Avendaño, S.; Bárcenas, C.; Sales-Morales, S. An outline of our current knowledge on Mexican cycads (Zamiaceae, Cycadales). Curr. Top. Plant Biol. 2003, 4, 159-174.

35. Benson, D.; McDougall, L. Ecology of Sydney Plant Species Part 1. Ferns, fern-allies, cycads, conifers and dicotyledon familes Acanthaceae to Asclepiadaceae. Cunninghamia 1993, 3, 257-422. 
36. Pate, J.S. Biology of the S.W. Australian cycad Macrozamia riedlei (Fisch. ex Gaudich.) C.A.Gardn. In The Biology, Structure, and Systematics of the Cycadales; Stevenson, D.W., Norstog, K.J., Eds.; Palm \& Cycad Societies of Australia Ltd.: Milton, Australia, 1993; pp. 125-130.

37. Elith, J.; Kearney, M.; Phillips, S. The art of modelling range-shifting species. Meth. Ecol. Evol. 2010, 1, 330-342.

38. Fordham, D.A.; Akçakaya, H.R.; Araújo, M.B.; Elith, J.; Keith, D.A.; Pearson, R.; Auld, T.D.; Mellin, C.; Morgan, J.W.; Regan, T.J.; Tozer, M.; Watts, M.J.; White, M.; Wintle, B.A.; Yates, C.; Brook, B.W. Plant extinction risk under climate change: are forecast range shifts alone a good indicator of vulnerability to global warming? Global Change Biol. 2012, 18, $1357-1371$.

39. Jones, D.L.; Forster, P.I. Seven new species of Macrozamia section Parazamia (Miq.) Miq. (Zamiaceae) from Queensland. Austrobaileya 1994, 4, 269-288.

40. Elith, J. Threatened Species Map Updates. Species Distribution Modelling Part 1: Report to the Victorian Department of the Environment, Water, Heritage and the Arts; The University of Melbourne: Melbourne, Australia, 2008.

41. ANU. ANUCLIM. Available online: http://fennerschool.anu.edu.au/research/publications/ software-datasets/anuclim (accessed on 25 November 2012).

42. CSIRO. Exploring climate change scenarios for Australia. Available online: http://www.csiro.au/ ozclim/home.do (accessed on 25 November 2012).

43. VanDerWal, J.; Shoo, L.P.; Graham, C.; Williams, S.E. Selecting pseudo-absence data for presence-only distribution modelling: How far should you stray from what you know? Ecol. Modell. 2009, 220, 589-594.

44. Phillips, S.J.; Anderson, R.P.; Schapire, R.E. Maximum entropy modelling of species geographic distributions. Ecol. Modell. 2006, 190, 231-259.

45. Raes, N.; ter Steege, H. A null-model for significance testing of presence-only species distribution models. Ecography 2007, 30, 727-736.

46. Savolainen, V.; Forest, F. Species-level phylogenetics from continental biodiversity hotspots. In Plant Species-Level Systematics: New Perspectives on Pattern and Process; Bakker, F.T., Chatrou, L.W., Gravendeel, B., Pelser, P.B., Eds.; Lubrecht \& Cramer Ltd: New Windsor, NY, USA, 2005; pp. 17-30.

47. Seymour, R.S.; Terry, I.; Roemer, R.B. Respiration and thermogenesis by cones of the Australian cycad Macrozamia machinii. Funct. Ecol. 2004, 18, 925-930.

48. Roemer, R.B.; Terry, I.; Chockley, C.; Jacobsen, J. Experimental evaluation and thermo-physical analysis of thermogenesis in male and female cycad cones. Oecologia 2005, 144, 88-97.

49. Roemer, R.B.; Terry, L.I.; Walter, G.H. Unstable, self-limiting thermochemical temperature oscillations in Macrozamia cycads. Plant Cell Environment 2008, 31, 769-782.

50. Bykova, O.; Chuine, I.; Morin, X.; Higgins, S.I. Temperature dependence of the reproduction niche and its relevance for plant species distributions. J. Biogeogr. 2012, doi:10.1111/j.13652699.2012.02764.x. 
51. Schemske, D.W.; Husband, B.C.; Ruckelshaus, M.H.; Goodwillie, C.; Parker, I.M.; Bishop, J.G. Evaluating approaches to the conservation of rare and endangered plants. Ecology 1994, 75, 584-606.

(C) 2012 by the authors; licensee MDPI, Basel, Switzerland. This article is an open access article distributed under the terms and conditions of the Creative Commons Attribution license (http://creativecommons.org/licenses/by/3.0/). 